\title{
THE NEEDS OF CONTINUING VOCATIONAL TRAINING OF SOCIAL WORK SPECIALISTS PROVIDING SOCIAL SERVICES
}

\author{
Venelin Terziev \\ Professor, Ph.D., D.Sc. (National Security), D.Sc. (Ec.), University of Rousse, Rousse, Bulgaria; \\ National Military University, Veliko Tarnovo, Bulgaria; University of Telecommunications and Post, \\ Sofia, Bulgaria, terziev@skmat.com
}

\begin{abstract}
This study justifies the need for building a system for research, identification and monitoring of the needs of vocational training in compliance to the constantly changing needs of the labour market. When considered in a narrower sense this problem justifies and proves the need for this activity related to social work and social workers. A method for determining the need for continuing vocational training of specialists in social work is developed and an experimental model for its implementation is offered.
\end{abstract}

Keywords: social management, social activities, continuing vocational training.

\section{INTRODUCTION}

Since 1997 in Bulgaria a reform is carried out in the field of offering vocational education and training that corresponds to the changing needs of the labour market. Support has been given by number of programs and projects that represent a platform for continuation of the reform aiming to transform strategic planning into practical reality.

In the basis of building the system for research, identification and monitoring of the needs for vocational training is the philosophy for communication on the labour market, in some countries understood as social dialogue (Scheme 1). 


\begin{tabular}{|c|c|c|}
\hline Ministry of Finance & $\begin{array}{l}\text { Ministry of Labor } \\
\text { and Social Policy }\end{array}$ & $\begin{array}{l}\text { Ministry of } \\
\text { Education and } \\
\text { Science }\end{array}$ \\
\hline
\end{tabular}

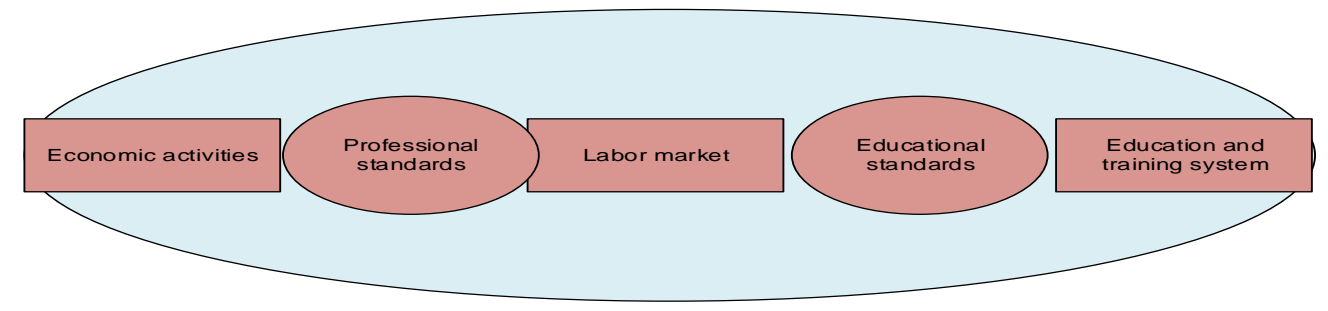

Scheme 1: Communication on the labour market

The above scheme shows the place and role of the main partners of the labour market, representatives of the government administrations and social partners. The effectiveness of functioning of such a communication system depends exclusively on the political will and political attitude for communication of all interested parties. In case of presence of suitable legislation and qualified and motivated experts and employees in those institutions that perform key roles in the systems, the aggregate of the upper two attitudes will have positive contribution to the development of the country. (2002a-c,2003ae,2004,2005,2012a-b,2014a-c)

The analysis of the labour market in Bulgaria shows serious deficits in regards to communication both between the separate public institutions and between institutions on one hand and employers, employees and officers on the other hand. In regards to the general situation on the labour market in Bulgaria and the condition of the vocational education and training, the representatives of institutions from the field of employment and social policy unanimously highlight the need for fundamental changes in the cooperation between partners on the labour market, but also in the contents of the work as quality control of educational and training services, collection and analysis of information about the employers' needs of qualified staff, compliance of the offered education and qualification with the needs of employers and others. (2012c-d, 2014c-f, 2015a-j, 2016a-c).

Systematic communication on the labour market requires equal in rights and responsibilities participation of all partners on the labour market regardless of whether they are governmental structures or employers, employees and officers' representatives, vocational training centres, district and municipal administrations, non-governmental organizations and others. In this way each one of the partners may receive trustworthy information if before that they themselves have provided trustworthy information to other partners. (2002a-c, 2003a-d, 2012c-d, 2013a-b, 2014e-f, 2015a-j, 2016a-c)

Along with all studies that aim to foresee the future development, the forecasts about the needs for qualification and skills are characterized by some uncertainty of anticipated results and expected effects. The introduction of future oriented system for labour market development, which includes analysis of the needs for skills, is a good step. But in reality it is not enough. Such a system can be useful only if it constitutes a part of a broader system. Broader systems provide information and ensure professional communication between all interested parties in the socio-economic sphere. The workforce of our country is one of the most important resources that it has and therefore the quality of the workforce should be present as a major component both in the plans for economic development of the country and in its policy regarding vocational education and training. It is preferable that such an approach is implemented in close cooperation and continuous communication with all interested people, ministries and social partners.

\section{OBJECTIVE AND TASKS OF THE NEEDS OF CONTINUING VOCATIONAL TRAINING OF SOCIAL WORK SPECIALISTS PROVIDING SOCIAL SERVICES}

The objective of the methodology for determining the needs of continuing vocational training of social work specialists providing social services is to increase the level of correlation between demand and supply on the labour market that should contribute for improving the workforce quality in the country as competitive factor with increasing significance for the successful economic development.

In this regard realistic human resource planning should be achieved based on systematic observation and knowledge of the workforce's condition. The collected data must support the process of decision-making in 
the field of employment, labour market, vocational education and training, higher education, workforce development at national and regional level.

The expectation is that in future the organizations in Bulgaria will more and more often pay attention to quality and improvement of its workforce's skills. The sharp deficit of qualified workers and employees is present even now and in many of the economic sectors in the country, that is why the methodology will cooperate to the managerial and entrepreneurial decisions in the Bulgarian organizations.

For the purposes of achieving this goal should be created an organized mechanism connecting ministries, government agencies, social partners, employment agencies - private or public, chambers of commerce, institutions for vocational education and training, employers and employees' organizations.

Such organized mechanism shall work by performing consequently, in a certain manner and without interruption, a number of research and analytical steps, as well as such steps related to information dissemination and ensuring constant feedback.

Studying and determining the needs of continuing vocational training of social work specialists providing social services is herein considered as a process that starts with the analysis of the labour market, passes through the following steps up to the development of curriculums, programs and modules and by means of feedback again and continuously passes through the methodology's number of steps.

\section{STUDYING THE NEEDS FOR CONTINUING VOCATIONAL EDUCATION IN DEPARTMENTS 'CHILD WELFARE' AND 'PEOPLE WITH DISABILITIES AND SOCIAL SERVICES' AT THE 'SOCIAL ASSISTANCE' DIRECTORATES OF THE SOCIAL ASSISTANCE AGENCY FOR INCREASING THE QUALITY AND EFFICIENCY OF SOCIAL WORK}

Objective of the study of the needs for continuing vocational education in departments 'Child Welfare' and 'People with disabilities and social services' at the 'Social Assistance' directorates of the Social Assistance Agency for increasing the quality and efficiency of social work

The objective of the study of the needs for continuing vocational education in departments 'Child Welfare' and 'People with disabilities and social services' at the 'Social Assistance' directorates of the Social Assistance Agency for increasing the quality and efficiency of social work is to determine the needs of adequate training courses and the measures for support of the social workers with the purpose of achieving better efficiency of social work in the context of lifelong learning and continuing vocational training. The objective of the study of the needs for continuing vocational education is also to identify acceptable options for ensuring continuous adequate introductory and advanced training of employees for increasing their qualification to work with different groups of users. As a result of the study's analysis will be outlined the basic needs of continuing vocational training for employees of the two departments. In order to achieve maximum accuracy surveys are directed also to studying the opinion of the Chiefs of directorates, Head of Department and Senior experts in 'Child Welfare' and 'People with disabilities and social services' at the 'Social assistance' directorates of the Social Assistance Agency which form part of the target group.

Tools of the study of the needs for continuing vocational education in departments 'Child Welfare' and 'People with disabilities and social services' at the 'Social Assistance' directorates of the Social Assistance Agency for increasing the quality and efficiency of social work

\section{Information sources}

Information from the following sources was used for the study:

- Specialized questionnaires for employees in the departments 'Child Welfare' and 'People with disabilities and social services' at the 'Social Assistance' directorates of the Social Assistance Agency

- Specialized questionnaires for Chiefs of directorates, Head of Department and Senior experts in 'Child Welfare' and 'People with disabilities and social services' at the 'Social assistance' directorates of the Social Assistance Agency

Questionnaires are a tool for achieving three main objectives:

1. Collecting information about the specific needs of training and qualification of the Social Assistance Agency employees;

2. Identification and prioritization of the specific needs and topics of training; 
3. Determining the target groups, types and forms of qualification needed by the employees of the departments 'Child Welfare' and 'People with disabilities and social services' at the 'Social Assistance' directorates and Chiefs of directorates, Head of Department and Senior experts in 'Child Welfare' and 'People with disabilities and social services' at the 'Social assistance' directorates of the Social Assistance Agency.

\section{Determining the target group}

The target group is generally defined - the employees of departments 'Child Welfare' and 'People with disabilities and social services' at the 'Social Assistance' directorates, whose survey will provide possibility for completion of the process of identification of the needs for continuing vocational training. The survey's result analysis will outline the basic needs for education of the employees in the two departments. In order to achieve maximum accuracy surveys are directed also to studying the opinion of the Chiefs of directorates, Head of Department and Senior experts in 'Child Welfare' and 'People with disabilities and social services' at the directorates 'Social assistance' of the Social Assistance Agency which form part of the target group.

\section{Study instructions}

For the purposes of studying the needs of continuing vocational training in departments 'Child Welfare' and 'People with disabilities and social services' at the 'Social Assistance' directorates of the Social Assistance Agency was developed an instruction for the survey that indicates the steps and the more important moments in the immediate collection of information by answering the questionnaires. The instruction contains the main requirements and is a guideline in the process of information collection, such as:

- What is the study's performance, what are its objectives, who implements it;

- How are the employees subject to study determined;

- Requirements for accuracy of information, precision of filling-in;

- Specific questions and requirements for them;

- Deadline for sending the filled questionnaires and exact mailing address.

Separate questionnaires are developed for each of the target groups (employees in the departments 'Child Welfare' and 'People with disabilities and social services' at the 'Social Assistance' directorates and Chiefs of directorates, Head of Department and Senior experts in 'Child Welfare' and 'People with disabilities and social services' at the directorates 'Social assistance' of the Social Assistance Agency). The questionnaire for the employees in departments 'Child Welfare' and 'People with disabilities and social services' at the 'Social Assistance' directorates of the Social Assistance Agency is anonymous in order to collect trustworthy information.

\section{Making the questionnaire for the employees in departments 'Child Welfare' and 'People with disabilities and social services' at the 'Social Assistance' directorates}

In the questionnaires the questions are divided into three sections:

Section I. General profile of the respondents - includes questions related to gender, age, last completed education, last completed qualification, current position and work experience in the social field. The questions are common for the two departments.

Section II. Competence level of experts and social workers is divided in two parts, common for the two departments.

Part A. Knowledge of the social work by the respondents - includes questions for determining how knowledge for social work (formal and informal) help social workers to carry out activities such as information, active listening, assessing client needs, maintaining positive working relationships with clients, preparing individual plans for work with clients, planning and management of intervention, setting the priorities at work.

Part B. Social workers' skills of the respondents - includes questions for determining the obtained by social workers skills for social work by considering different points of view in collection of information, efficient contact with people, planning the actions for achieving the given objective, establishing working relationships, maintaining positive working relationships, applying ethic principles of social work, identification of risk situations, analysis of risk and potential damages both for themselves and for other people, job satisfaction.

Section III. Need of trainings and career growth of the respondents. This section includes different questions for the two departments in order to achieve maximum accuracy when determining the need of adequate trainings such as already held introductory trainings, types of trainings, further training compliant with time 
and place, duration, professional and career growth, additional trainings in different fields, required supervision.

\section{Making a questionnaire for Chiefs of directorates, Head of Department and senior experts in 'Child Welfare' and 'People with disabilities and social services' at the 'Social assistance' directorates of the Social Assistance Agency}

The purpose of this survey is to determine the competences level of those working in the departments 'Child Welfare' and 'People with disabilities and social services' at the 'Social assistance' directorates of the Social Assistance Agency from the perspective of managers. It contains two sections:

Section I. Interview of an immediate manager - includes questions related to review of the overall operational work such as daily tasks, responsibilities, requirements towards work, efficient communication with clients and colleagues, level of satisfaction, signs of insufficient team motivation.

Section II. Competence level of those working in the departments 'Child Welfare' and 'People with disabilities and social services' at the 'Social assistance' directorates of the Social Assistance Agency from the perspective of managers - includes questions for determining the intentions for positive communication in the work with clients, skills for teamwork and sharing of experience, for work with documents in the provision of social services, skills for work with difficult or disadvantaged clients, attitudes for self-assessment of their own qualities and deficits, the need of additional vocational (training) qualification and supervision by types.

\section{Processing of questionnaires}

The following procedural steps have to be passed through for the processing of the information collected from the questionnaires:

- Creating a matrix for entering of information (depending on the chosen statistical programme for information processing is created a matrix with variables corresponding strictly to the structure and order of the variables in the questionnaire. For each question there should be the required number of variables; single questions are entered in one variable and the multiple ones - in the relevant number of variables depending on the answer options. Tabloid questions should have number of variables equal to $\mathbf{n}$ * $\mathbf{k}$ where $\mathbf{n}$ is the number of rows of the table, and $\mathbf{k}$ is the number of columns. Each variable in the matrix is represented by a name logically correlating with the number of questions and if necessary the contents of the question (e.g. q8_1_male_2013, q 8_male_2014 etc.).

- Entering information or converting the collected information in numerical order, which is subsequently suitable for quantitative processing; numerical values corresponding to each of the options provided in the questionnaire are entered; depending on the type of questions for each variable are possible different number of replies and their corresponding numerical expressions - e.g., at certain points we have only a combination of 0 and 1, 0 and 2, 0 and 3, etc. In other questions are possible answers from 1 to 5 and so on. Generally, for each variable the possible digital options are determined by the codes set in the questionnaire and the logical presentation of the matter.

- Statistical processing - for the statistical processing in this case are suitable one-dimensional and twodimensional allocations, arithmetic mean, median and mode, statistical significance tests and hypothesis testing.

Depending on the selected statistic program, static processing can be obtained by pressing the function keys or writing a program as an algorithm (in the relevant programming language or language commands). The so presented statistical model enables us to make summaries both at the level of measurement and in terms of trends (comparisons of results over time).

\section{ANALYSIS OF THE RESULTS OF THE STUDY ON THE NEEDS OF CONTINUING VOCATIONAL TRAINING FOR EXPERTS AND SOCIAL WORKERS}

The questionnaire intended for the employees of the departments 'Child welfare' was made to be filled-in on a hard copy, including 23 pages. 767 respondents filled it in and returned it, and $\mathbf{4 6 8}$ of them responded to all questions in the questionnaire.

The questionnaire had totally 76 questions divided into sections. 11 are the questions requiring general information, 62 are with an option of choosing only one answer, 3 - with an option of choosing more than one answer, 2 are open questions and 1 question for prioritization and giving more than one answer.

The distribution of respondents by gender is presented in table 1. From these data it becomes clear that greatest is the percentage age of social workers - women $-90.6 \%$ of the total number. 
Table 1

\begin{tabular}{|c|c|c|c|c|c|}
\hline \multicolumn{2}{|c|}{ Gender } & Frequency & Percentage age & Valid percentage & $\begin{array}{c}\text { Cumulative } \\
\text { percentage }\end{array}$ \\
\hline & Man & 71 & 9,3 & 9,3 & 9,3 \\
\cline { 2 - 6 } & Woman & 695 & 90,6 & 90,7 & 100,0 \\
\cline { 2 - 6 } & Total responded & 766 & 99,9 & 100,0 & \\
\hline & Not responded & 1 &, 1 & & \\
\hline Total & 767 & 100,0 & & \\
\hline
\end{tabular}

Interesting is the fact that $\mathbf{4 8 . 5} \%$ of the respondents are aged between 36 and 55 years, 33,8\% are aged 26-35 years and only $\mathbf{1 2 , 1} \%$ are up to 25 years. (Table 2 )

Table 2

\begin{tabular}{|c|c|c|c|c|}
\hline Age & Frequency & Percentage & Valid percentage & $\begin{array}{c}\text { Cumulative } \\
\text { percentage }\end{array}$ \\
\hline Up to 25 years & 93 & 12,1 & 12,2 & 12,2 \\
\hline From 26 to 35years & 259 & 33,8 & 33,9 & 46,1 \\
\hline From 36 to 55 years & 372 & 48,5 & 48,7 & 94,8 \\
\hline Over 56 & 40 & 5,2 & 5,2 & 100,0 \\
\hline Total responded & 764 & 99,6 & 100,0 & \\
\hline Not responded & 3 & 0,4 & & \\
\hline Total & 767 & 100,0 & & \\
\hline
\end{tabular}

To the question about the type of the last completed education, $\mathbf{8 5 . 9 \%}$ answered that they have University degree of which $\mathbf{5 1 . 0 \%}$ have Master academic degree and $\mathbf{3 4 . 9 \%}$ have bachelor academic degree. Employees with secondary education are total $\mathbf{1 3 . 8 \%}$

Interesting information provides the question 'Year of completing the last education'. As it may be seen from table 8, the number of graduates begins to increase from $1995-2.2 \%, 2000-5.4 \%, 2005-5.9 \%, 2011$ - $8.2 \%$ compared to $1972-0.4 \%, 1977-0.5 \%, 1982-0.7 \%, 1990-0.8 \%$.

The distribution of the respondents according to their obtained last vocational qualification is shown in table 3.

Table 3

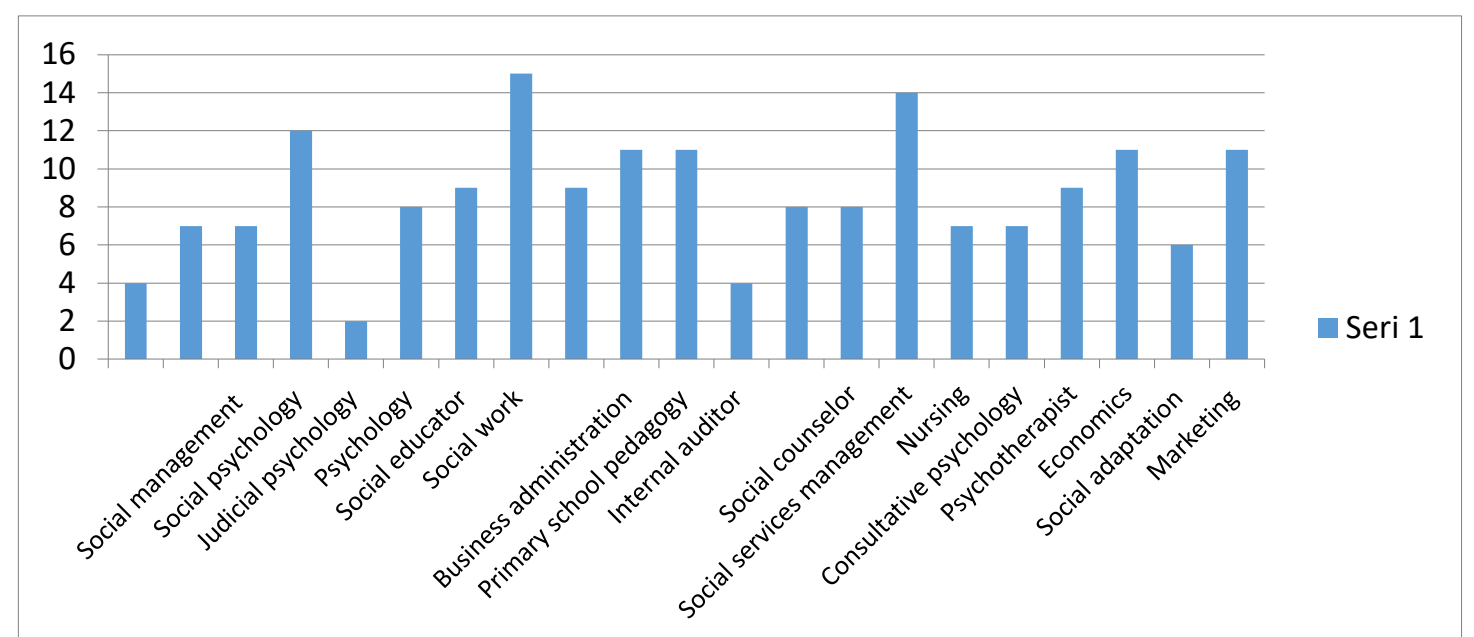

The distribution of the respondents according to their obtained last qualification in key competence/certification course is shown in table 4. 
Table 4

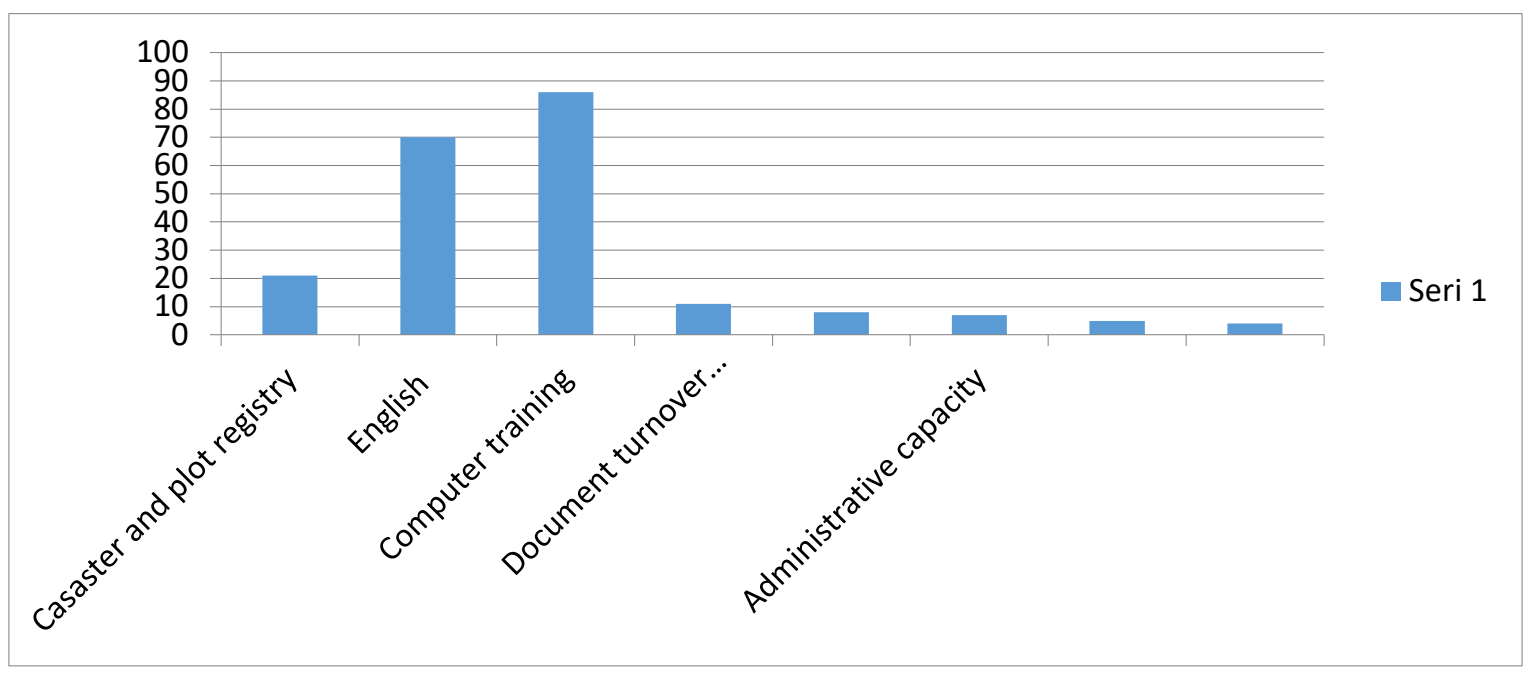

The distribution of the respondents according to their experience in the social field is shown in table 5 of which it is evident that the greatest percentage $\mathbf{- 4 2 . 4 \%}$ is for employees with experience up to 2 years and only $4.6 \%$ of those with experience over 20 years. $1.7 \%$ of the inquired people did not provide an answer.

Table 5

\begin{tabular}{|c|c|c|c|c|}
\hline Experience in the social field & Frequency & Percentage & $\begin{array}{c}\text { Valid } \\
\text { percentage }\end{array}$ & $\begin{array}{l}\text { Cumulative } \\
\text { percentage }\end{array}$ \\
\hline Up to 2 years & 320 & 41,7 & 42,4 & 42,4 \\
\hline From 2 to 10 years & 243 & 31,7 & 32,2 & 74,7 \\
\hline From 11 to 20 years & 156 & 20,3 & 20,7 & 95,4 \\
\hline Over 20 years & 35 & 4,6 & 4,6 & 100,0 \\
\hline Total responded & 754 & 98,3 & 100,0 & \\
\hline Not responded & 13 & 1,7 & & \\
\hline Total & 767 & 100,0 & & \\
\hline
\end{tabular}

To the question 'Do you make yourself familiar with the available information before you start work on a particular case', 694 respondents answered 'always in details', which is $91 \%$. A negative answer 'there is always lack of information' is given by $2.2 \%$, i.e. 17 employees. Four people did not provide an answer.

For receiving additional information that may be useful when establishing initial contact $53.7 \%$ of the respondents answered 'always', and 39.3\% - 'I contact if necessary'. This is an indicative result of good teamwork and quality performance.

To the question 'Do you assess all the available information to determine the best way of initial contact?', $\mathbf{8 3 . 6 \%}$ of social employees answer 'always in details' and only $\mathbf{4 . 9 \%}$ are those who answered 'I don't make assessments, I start work'.

To the open question about what causes the difficulties in the performance of the activities in social work as a whole, are given answers comprising issues in 20 areas. In the first place, with $\mathbf{2 0 . 2} \%$ are answers stating that there is lack of equipment and supplies in the workplace. Secondly, with $9.6 \%$ are answers emphasising on big workload and many work cases. In third place with $\mathbf{7 . 0 \%}$ are answers stating lack of suitable facilities and poor working conditions. In fourth place, $\mathbf{5 . 1 \%}$ say that there is no assistance on behalf of the users. In the fifth place, with $4.4 \%$ are answers stating lack of organized transport and big distance of the workplace to the clients. Interesting is the fact that all 767 social workers from the departments 'Child Welfare' answered this question. The results are shown in details in Chart 1. 


\section{Chart 1}

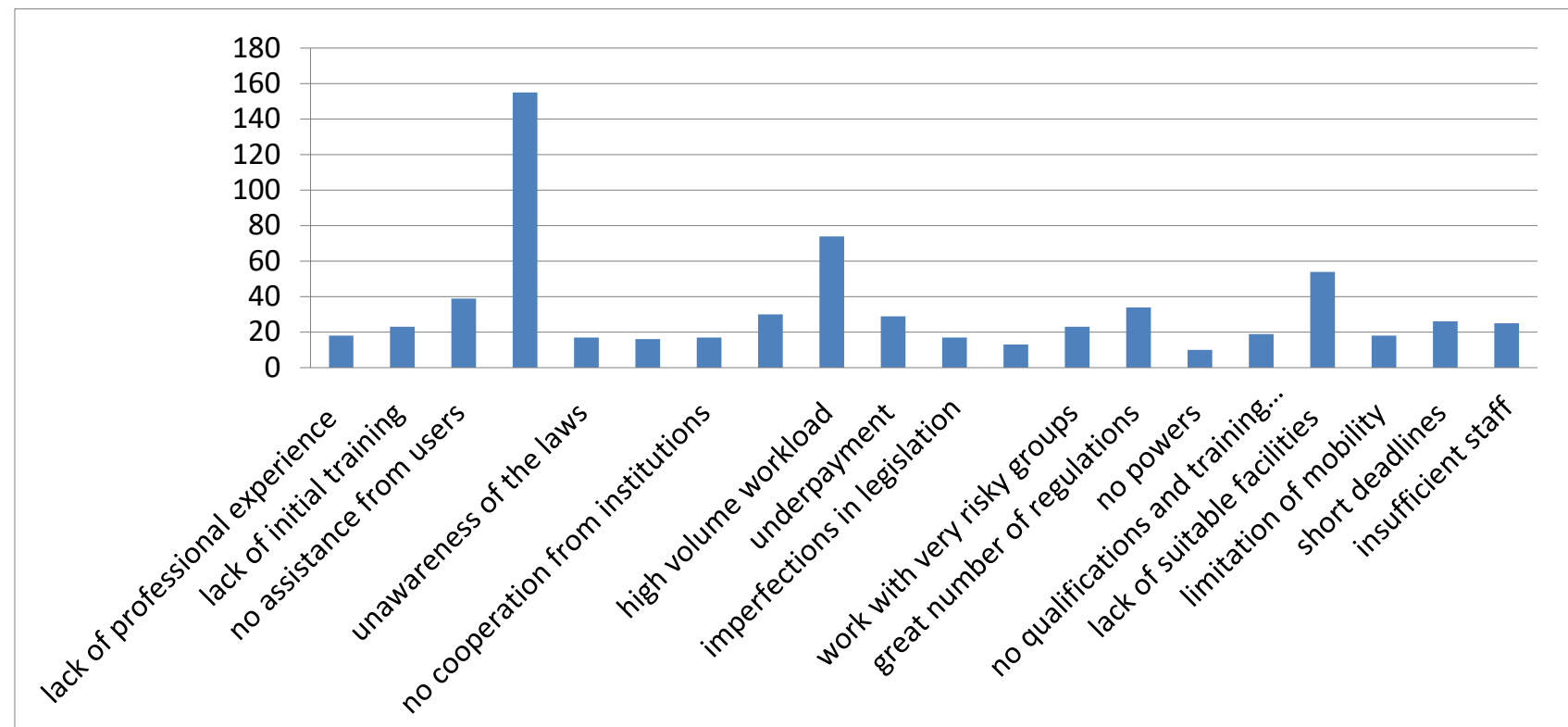

For the mastering of their professional duties and fulfilling them without problems $42.2 \%$ of the respondents said that they need 'more than 4 weeks', and $22.9 \%$ - 'up to 4 weeks'. $16.0 \%$ still have problems with performance. 19 employees couldn't decide and did not answer this question. Data are shown in table 6.

Table 6

\begin{tabular}{|c|c|c|c|c|}
\hline $\begin{array}{l}\text { When you started work, how long did it } \\
\text { take you to master your professional duties } \\
\text { and fulfil them smoothly? }\end{array}$ & \multirow{2}{*}{$\begin{array}{l}\text { Frequency } \\
27\end{array}$} & \multirow{2}{*}{$\begin{array}{c}\text { Percentage } \\
3.5\end{array}$} & \multirow{2}{*}{$\begin{array}{c}\begin{array}{c}\text { Valid } \\
\text { percentage }\end{array} \\
3.6\end{array}$} & \multirow{2}{*}{$\begin{array}{c}\text { Cumulative } \\
\text { percentage } \\
3.6\end{array}$} \\
\hline 1 week & & & & \\
\hline Up to 2 weeks & 48 & 6.3 & 6.4 & 10.0 \\
\hline Up to 3 weeks & 66 & 8.6 & 8.8 & 18.9 \\
\hline Up to 4 weeks & 171 & 22.3 & 22.9 & 41.7 \\
\hline More than 4 weeks & 316 & 41.2 & 42.2 & 84.0 \\
\hline I still have difficulties in fulfilment & 120 & 15.6 & 16.0 & 100.0 \\
\hline Total responded & 748 & 97.5 & 100.0 & \\
\hline Not responded & 19 & 2.5 & & \\
\hline Total & 767 & 100.0 & & \\
\hline
\end{tabular}

The skills for social work of the respondents correspond to their knowledge. When studying and analysing the results from part $B$ it was found that there is an absolute percentage ratio between knowledge and skills for questions from 1 to 16 and from 19 to 21 in part $B$ of the questionnaire.

To the question 'Do you make distinction between different intervention theories, policies, procedures and methods?' $75.7 \%$ of the respondents do not encounter any difficulties and $20.9 \%$ are managing but encounter significant difficulties. A small part of the employees $-3.3 \%$ cannot manage and rely on their colleagues' help. Seven social workers did not answer this question as may be seen in table 7.

Table 7

\begin{tabular}{|c|c|c|c|c|}
\hline $\begin{array}{l}\text { Do you make distinction between different } \\
\text { intervention theories, policies, procedures } \\
\text { and methods? }\end{array}$ & Frequency & Percentage & $\begin{array}{c}\text { Valid } \\
\text { percentage }\end{array}$ & $\begin{array}{l}\text { Cumulative } \\
\text { percentage }\end{array}$ \\
\hline \begin{tabular}{c|c} 
Yes, absolutely \\
\end{tabular} & 575 & 75.0 & 75.7 & 75.7 \\
\hline $\begin{array}{c}\text { Yes, but I encounter significant } \\
\text { difficulties }\end{array}$ & 159 & 20.7 & 20.9 & 96.6 \\
\hline $\begin{array}{l}\text { I can't manage because I encounter } \\
\text { extremely serious difficulties }\end{array}$ & 1 & 0.1 & 0.1 & 96.7 \\
\hline $\begin{array}{c}\text { I can't manage, I rely on my colleagues' } \\
\text { help }\end{array}$ & 25 & 3.3 & 3.3 & 100.0 \\
\hline
\end{tabular}


IJAEDU- International E-Journal of Advances in Education, Vol. 3, Issue 8, August 2017

\begin{tabular}{|c|c|c|c|c|c|}
\hline & Total responded & 760 & 99.1 & 100.0 & \\
\hline & Not responded & 7 & 0.9 & & \\
\hline Total & 767 & 100.0 & & \\
\hline
\end{tabular}

When working with people in different problematic situations, $89.0 \%$ of the employees start analysing the consequences of social inequality, discrimination and social exclusion, and $9.3 \%$ encounter significant difficulties. $1.4 \%$ of the inquired social workers rely on their colleagues' help. Only three employees from 'Child welfare' department did not answer this question.

To the question about what type of trainings as an organizational form are needed for the employees in the "Child Welfare' department, with an option to combine few types, $43.6 \%$ of the respondents say that they need specialized, focused on practice training, $\mathbf{2 8 . 4 \%}$ of them prefer participation in a specialized forum with the purpose of best practice transfer. $14.3 \%$ say they need narrowly specialized talk, seminar, and $\mathbf{7 . 0 \%}$ prefer distant training. All participants answered this question as $59.4 \%$ of the social workers in the departments gave more than one answer. The results are shown in chart 2.

\section{Chart 2}

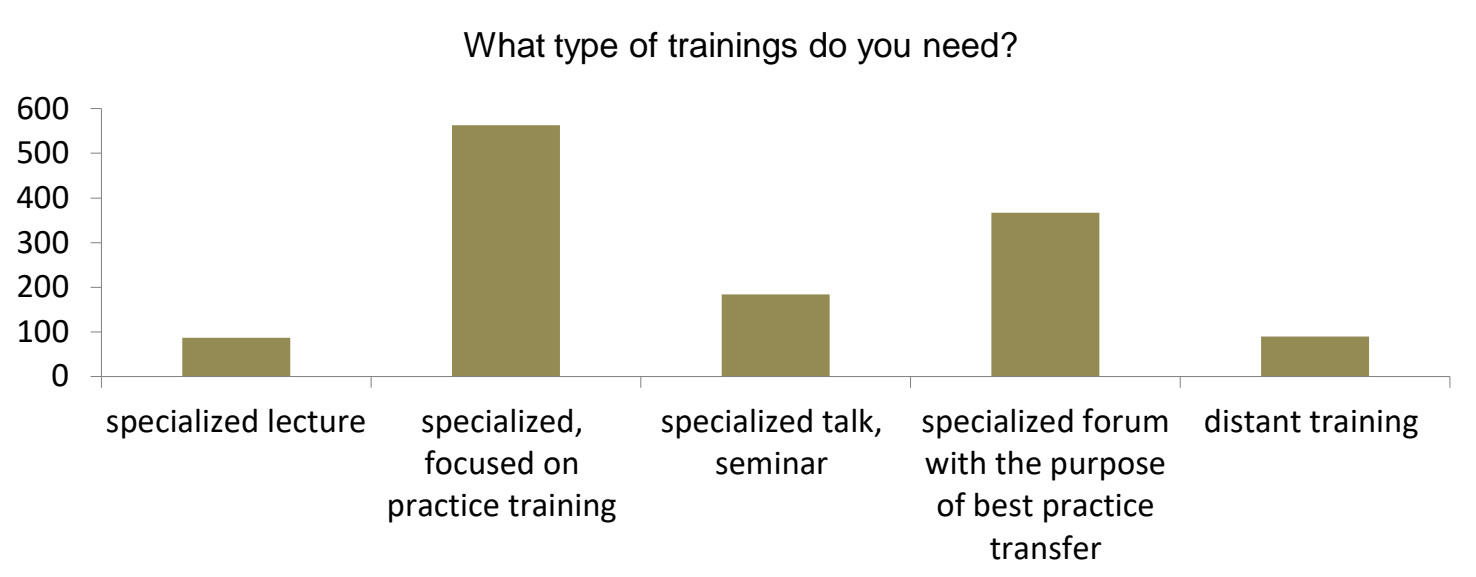

When asked about the time that the training in which respondents would participate should be held, $52.1 \%$ stated that it should be held during work, with almost equal numbers of rates $16.0 \%$ and $16.5 \%$ are employees who prefer trainings to be held after hours, up to 2 hours or in one day of the weekend. $8.8 \%$ of the respondents are ready to use few days of paid annual leave and to participate in advanced training, and $6.6 \%$ of the inquired social workers answered that trainings should be held during the weekend. Data are shown in Chart 3.

\section{Chart 3}

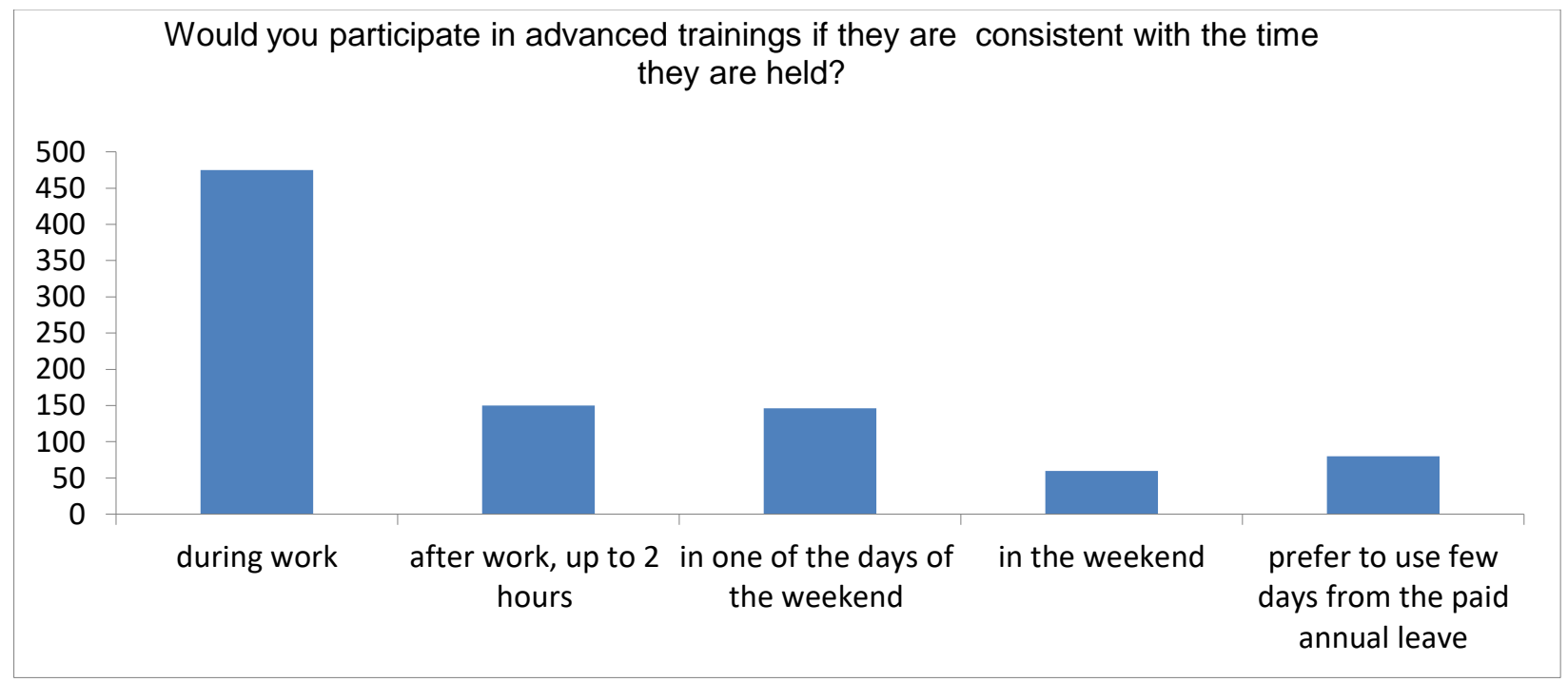

When asked about the place where the trainings in which respondents would participate should be held, $47.0 \%$ of the respondents answered that they prefer trainings that are held in the same place where they 
work. $30.4 \%$ are willing to travel and take part in trainings held elsewhere, and $22.7 \%$ prefer trainings to be held at the workplace. $80.1 \%$ of the employees gave one answer and the remaining $19.9 \%$ gave two answers. (Chart 4).

Chart 4

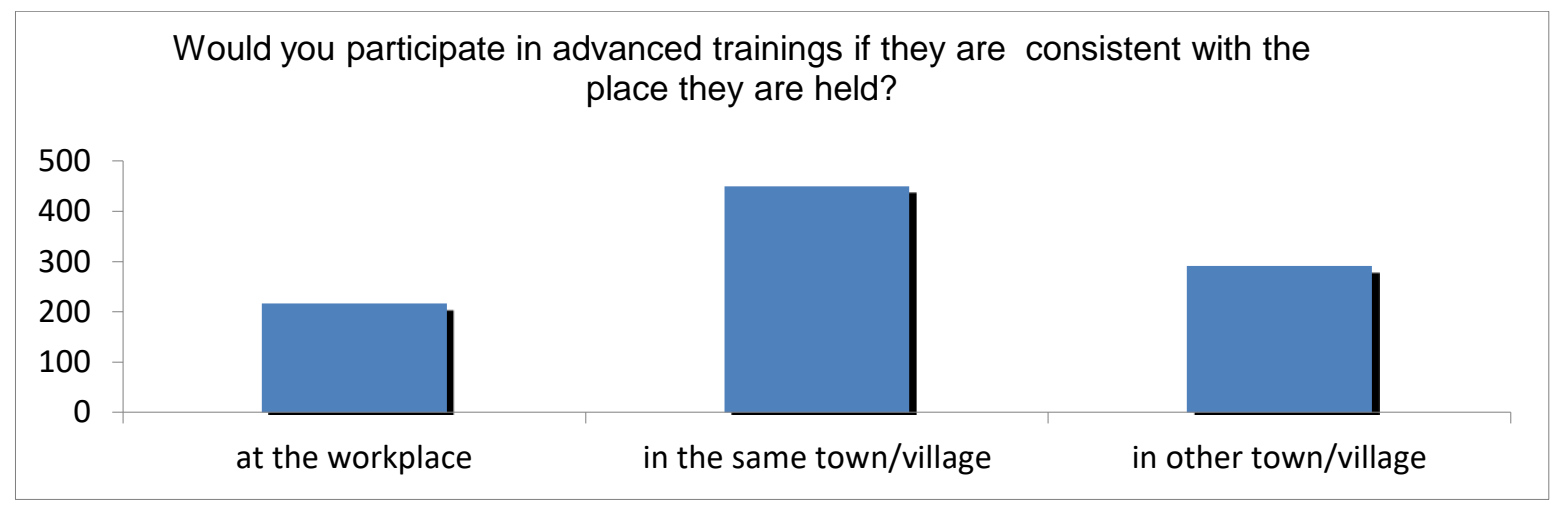

When asked about the optimum duration of the training in which the respondents would participate, $48.1 \%$ answered that it should be within a period of 3 days and $29.3 \%$ say they could spend up to 10 days (in modules) if needed to take part in training for improving their professional qualification. Only $14.9 \%$ say they would be able to participate in training that lasts up to 1 day. $7.7 \%$ of the departments' employees chose longer (more that 1 month) trainings in modules. Data are shown in Chart 5.

\section{Chart 5}

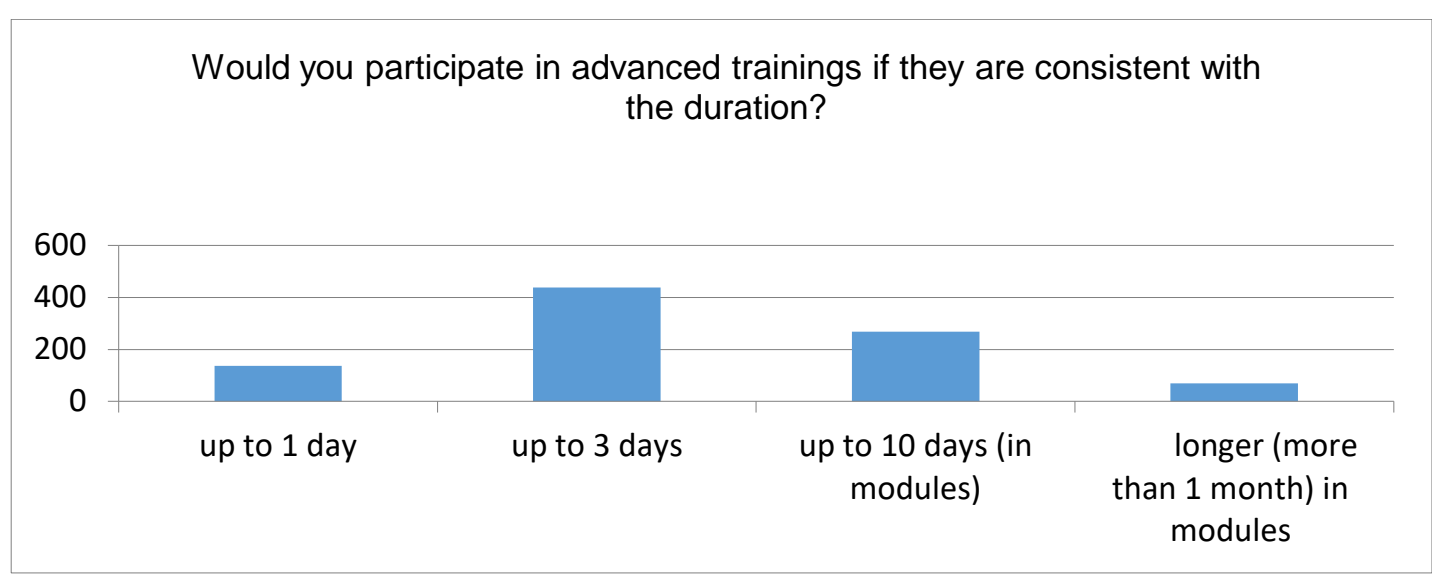

When asked to prioritize the main topics for introductory training of new social workers, the respondents had to choose one or combination of few of the following pre-defined topics:

- Social policy and legal framework in the field of child welfare

- Team management, teamwork and communication in social work

- Organizational behaviour in social work

- Social work with children and families at risk

- Organization and characteristics of the activities performed in a 'Child welfare' department

- The process of deinstitutionalization - social policies

- Fundamentals and methods in the social worker's job at nursery schools

- As most important, in the first place with $69.0 \%$ of all votes is the topic - Social work with children and families at risk; in the second place with $35.6 \%$ of the votes is chosen the topic Social policy and legal framework in the field of child welfare, and in the third place with $31.5 \%$ is the topic 'Fundamentals and methods in the social worker's job at nursery schools'.

As least important topic at the moment of the survey $13.3 \%$ of all respondents indicate the training in Organizational behaviour in social work. 
Results show that in the first place with $\mathbf{5 5 . 1 \%}$ is identified the topic for advanced training in 'Methods of working with children - victims of violence and their families'. In the second place is put the topic 'Methods of case management for children at risk' and in the third place with $\mathbf{3 7 . 7 \%}$ is the topic 'Methods for early diagnosis of the risk of abandonment of a child and prevention of abandonment'. In the fourth position with $36.4 \%$ - 'Foster care - an alternative form of raising children in a family environment - process and specifics', and in the fifth place with $34.4 \%$ is the topic - 'Work with children - victims of trafficking and their families'. All the five topics chosen in the first five positions are strongly specialized, generating constant dynamics in regards to the regulatory deeds and communication with the client.

In the questionnaire there was also a question about what supervision is needed by the employees in the 'Child welfare' department. The respondents were given 11 answer options. The purpose was to collect information about the necessity and to identify the need of the type and the reasons for supervision in near future. This would enable the Social Assistance Agency and in particular the teams in 'Child Welfare' departments to better plan the supervisions organized by them. The answers received comprise 11 different fields, most of which are not repeated and concern only the inquired individual. However, after the analysis of the results emerged several types of supervision that the respondents would like to make changes in view of the way they are being performed.

The results show that in the first place with $19.6 \%$ is identified the need of supervision that enables the employees to overcome professional stress and the occupational burnout syndrome in social work. In the second place with $15.6 \%$ is indicated the need of supervision that aims social workers to understand their skills and their strengths and weaknesses. In the third place, according to $14.07 \%$ of the respondents is required supervision commenting the practice of different social work methods. The purposes of all the three types of supervision taking the first positions are strongly specialized, generating constant dynamics in regards to the communication with the client, specialized institutions and administrative work.

\section{CONCLUSION}

This study justifies the need for building a system for research, identification and monitoring of the needs of vocational training in compliance to the constantly changing needs of the labour market. When considered in a narrower sense, this problem justifies and proves the necessity for this activity related to social work and social workers. Still the curriculums and the educational programs for training such specialists in the universities in Bulgaria do not correspond to the real, established needs, as well as to the specifics of the performed activities.

\section{REFRENCES LIST}

Терзиев, В., И. Аврамова (2002а), Социалната политика в контекста на Европейската интеграция и реализиране на изследване на възможностите за въвеждане на технологията „План за действие”, Сборник с доклади от $\mathrm{IV}^{\text {-та }}$ Национална научно-практическа конференция „Службите по заетостта и новите предизвикателства за реализиране на активната политика на пазара на труда", 14-15 май 2002 г.,

Терзиев, В. (2002b), Национална програма „От социални помощи към осигуряване на заетост”, „Труд и право", бр.11, София, ноември 2002г.

Терзиев, В. (2002c), Общините и социалното подпомагане, Информационен бюлетин „Реформата в местното самоуправление“, бр.12, Фондация зареформа в местното самоуправление, София, 2002г.

Коцева М., В. Терзиев, 3. Андреева (2003а), Проблеми на оценката на активните политики на пазара на труда, Пета национална конфреренция „Службите по заетостта и Европейския пазар на труда”, Русенски университет „Ангел Кънчев”, МТСП, АЗ, Русе, 29-30 май 2003г.

Терзиев, В., А. Делибашева (2003b), Социална подкрепа и партньрство в сфрерата на професионалното ориентиране за младежи и възрастни, Първа научно-практическа конференция с международно участие „Мрежи за професионално ориентиране за младежи и възрастни", Икономически университет, Варна, 4-5 юни 2003г.

Наньова, Ц., В. Терзиев (2003с), Осигуряване на заетост на лица в неравностойно положение. Финансово стимулиране на работодатели за разкриване на нови работни места. Адаптивност 
имобилност на работната сила, Юбилейна международна конференция „Трудът и неговата защита презXXI век", Университет за национално и световно стопанство, София, 29 май 2003г.

Терзиев, В. (2003d), Национална програма „От социални помощи към осигуряване на заетост”, Информационен бюлетин по труда, кн.2, София, 2003.

Терзиев, В. (2003е), Новият социален модел, като ефективна възможност за реализиране на активната политика на пазара на труда в България, Национална научно-практическа конференция „Гъвкавата заетост и проблеми на нейната регулация”, Пловдивски университет „Паисий Хилендарски”, Пловдив, 4 юли 2003г.

Терзиев, В., Ю. Младенов, М. Стойчев (2004), Изследване възможностите за трудовата реинтеграция на продължително безработни лица на пазара на труда чрез програма за заетост, УНИТЕХ'04, Габрово, 18-19 ноември 2004г. Том III.

Терзиев, В. (2005), Общ анализ на въздействието на програмата „От социални помощи към осигуряване на заетост” на националния трудов пазар, УНИТЕХ'05, Габрово, 24-25 ноември 2005г. Том III.

Терзиев, В., Ю. Младенов (2012a), Активна социална програма и нейното стратегическо преимущество, Научни трудове на Русенски университет „Ангел Кънчев”, Том 51, серия 5.1., Pyce, 2012г.

Терзиев, В. (2012b), Критерии и показатели за социална ефективност, Международна научна конфреренция, Сборник доклади, том III, Габрово, УНИТЕХ 16-17 ноември 2012г.

Димитрова, С., В. Терзиев (2014а), Предложения в области социального капитала, партнерства и сети. Развитие социальной экономики. Поддержка социальной инновации, Международная научно-практическая конференция „Экономические науки: теоретический и практический взгляд", 1 октября 2014, Уфа, Россия.

Терзиев, В., С. Димитрова (2014b), Определяне на критерии и показатели за социална ефективност, Юбилейна научна конференция 2014 „100 годиниавиационно образование в България”, Национален военен университет „Васил Левски”, 9-10 октомври 2014г., гр.Долна Митрополия.

Терзиев, В., С. Димитрова (2014c), Ролята на социалната политика в икономическото развитие, Юбилейна научна конференция 2014 „100 годиниавиационно образование в България”, Национален военен университет „Васил Левски”, 9-10 октомври 2014г., гр.Долна Митрополия.

Терзиев, В. (2014d), Социалното програмиране в системата на социалните категории, VII Международная научная конфреренция „Инновации в технологиях и образовании” (КузГТУ), Белово, Россия, 2014. Сборник статей часть 2.

Терзиев, В., Е. Арабска (2015a), Социалното програмиране в контекста на насърчаване на социалната активност. Юбилейна международна научна конференция „Социалните науки и развитието на обществото - теоретични и практически измерения”, Свищов, 30-31 октомври 2015 г.

Терзиев, В., Е. Арабска (2015b), Активните трансформации в политиките за функциониращ пазар на труда и за заетост. Научна конференция с международно участие „Иновации в образованието“, 25-27 септември2015г. ШУ „Епископ Константин Преславски“. Годишник на ШУ „Еп. Константин Преславски“, т.XIXD Педагогически факултет, ISSN 1314-6769, Научни трудове от конференция

Терзиев, В., Е. Арабска (2015c), Изграждането на функциониращ пазар на труда в периода на преход на българската икономика. Научна конференция с международно участие „Иновации в образованието“, 25-27 септември 2015г. ШУ „Епископ Константин Преславски“. Годишник на ШУ „Епископ Константин Преславски“, т. XIXD Педагогически фракултет, ISSN 1314-6769, Научни трудове от конференция, стр.82-95.

Терзиев, В., Е. Арабска (2015d), Мониторинг на активните политики на пазара натруда в България, Първа научно-практическа конференция с международно участие „Социална работа, мениджмънт и социално развитие: съвременни предизвикателства, перспективи и иновативни практики 2015", 1-2 октомври 2015, ТУ-Варна.

Терзиев, В. (2016а), Приложение на социалното програмиране в регулирането на социалното развитие: ефективни социални политики чрез насърчаване на социалната активност на човешкия ресурс. Годишник/СА „Д. А. Ценов”, Том CXIX, Свищов 2016. 
Терзиев, В., Е. Арабска (2016b), Основни профили на безработните лица в България. Четиринадесета младежка научно-практическа конференция, 19-20 април 2016г. Федерация на научнотехническите съюзи, София. Сборник доклади.

Терзиев, В., Е. Арабска (2016с), Динамика в уязвимите групи на пазарана труда в България. Четиринадесета младежка научно-практическа конференция, 19-20 април 2016г. Федерация на научно-техническитесъюзи, София. Сборник доклади.

Терзиев, В., П. Димитрова (2014е), Развитие системы социальной поддержки в Болгарии, Сборник статей Международной научно-практической конференции „Актуальные проблемы современной науки", Аэтерна (Уфо) 2014.

Терзиев, В. (2014f), Преслава Димитрова, Развитие структуры системы социальной поддержки Болгарии, Сборник статей Международной научно-практической конфреренции „Актуальные проблемы современной науки", Аэтерна (Уфра) 2014.

Terziev, V. (2012c), Social technology as a method for management of the social processes, International Conference "Trends in economics and management for the $21^{\text {st }}$ century“(2012), Brno, Czech Republic.

Terziev, V. (2012d), The active model of a social programme and its strategic advantage, International Conference "Trends in economics and management for the $21^{\text {st }}$ century" (2012), Brno, Czech Republic.

Terziev, V. (2013a), Social technology as a method for management of the social processes, International Conference on Business and Economy (ICBE) Interdisciplinary studies on a new economy, 5-7 June, Constanta, Romania, 2013.

Terziev, V. (2013b), The active model of a social programme and its strategic advantage, $12^{\text {th }}$ International Scientific Conference: Management Horizons in Changing Economic Environment\& Visions and Challenges, Kaunas, Lithuania on September 26-28, 2013.

Terziev, V., S. Dimitrova, E. Arabska (2015e), Linking active social policies to education and qualification problems on the labor market. Humanitarian approaches to the Periodic Law // Humanities and Social Sciences in Europe: Achievements and Perspectives. Proceedings of the 6th International symposium. „East West” Association for Advanced Studies and Higher Education. Vienna. 2015. ISBN-13 978-3-903063-01-3.

Terziev, V., S. Dimitrova, E. Arabska (2015f), „From social support to employment”: considering target groups' needs in actice social policies. Актуальные проблемы социально-экономических исследований: сборник материалов. VIII Международная научно-практическая конференция, (г.Махачкала, 24 января, 2015г.) Махачкала: ООО „Апробация”, 2015.

Terziev, V. $(2015 \mathrm{~g})$, Social programming in the system of sociological categories concerning market economy and labor market development in transition economy, Конференция „Культура. Духовность. Общество”, ЦРНС, Новосибирск, Россия, 2015.

Terziev, V., S. Dimitrova, E. Arabska (2015h), Social activity of human resources - a basis for effective social policy (Социалната активност на човешкия ресурс - основа за ефективна социална политика), Fifth international scientific and applicative conference KNOWLEDGE - WHO AND WHAT, 21-25 May 2015, Bansko, Bulgaria, Journal of Process Management (JPMNT) - New Technologies, International, The International Scientific Conference „KNOWLEDGE - WHO AND WHAT”(held in Bansko, 21-25 May 2015), Special Edition, Volume 9, May 2015.

Terziev, V., E. Arabska (2015i), Social policy and social programming: key implications concerning development of active labor market policies and employment. Proceedings of $17^{\text {th }}$ International Academic Conference, Vienna, June 21-24, 2015, IISES.

Terziev, V., S. Dimitrova (2015j), Social activity of the human factor, Alma Mater University of Sibiu National Conference with International participation, 28 -30 of May 2015, Sibiu, Romania. Sibiu Alma Mater University Journal, Seies SC. Social sciences, Vol.8, N1, 2015. 